
Bogdan TOFAN

Bazin olimpic acoperit Izvorani, piscina lotului olimpic de natație

Izvorani Olympic covered pool,

swimming pool of the Olympic

swimming team

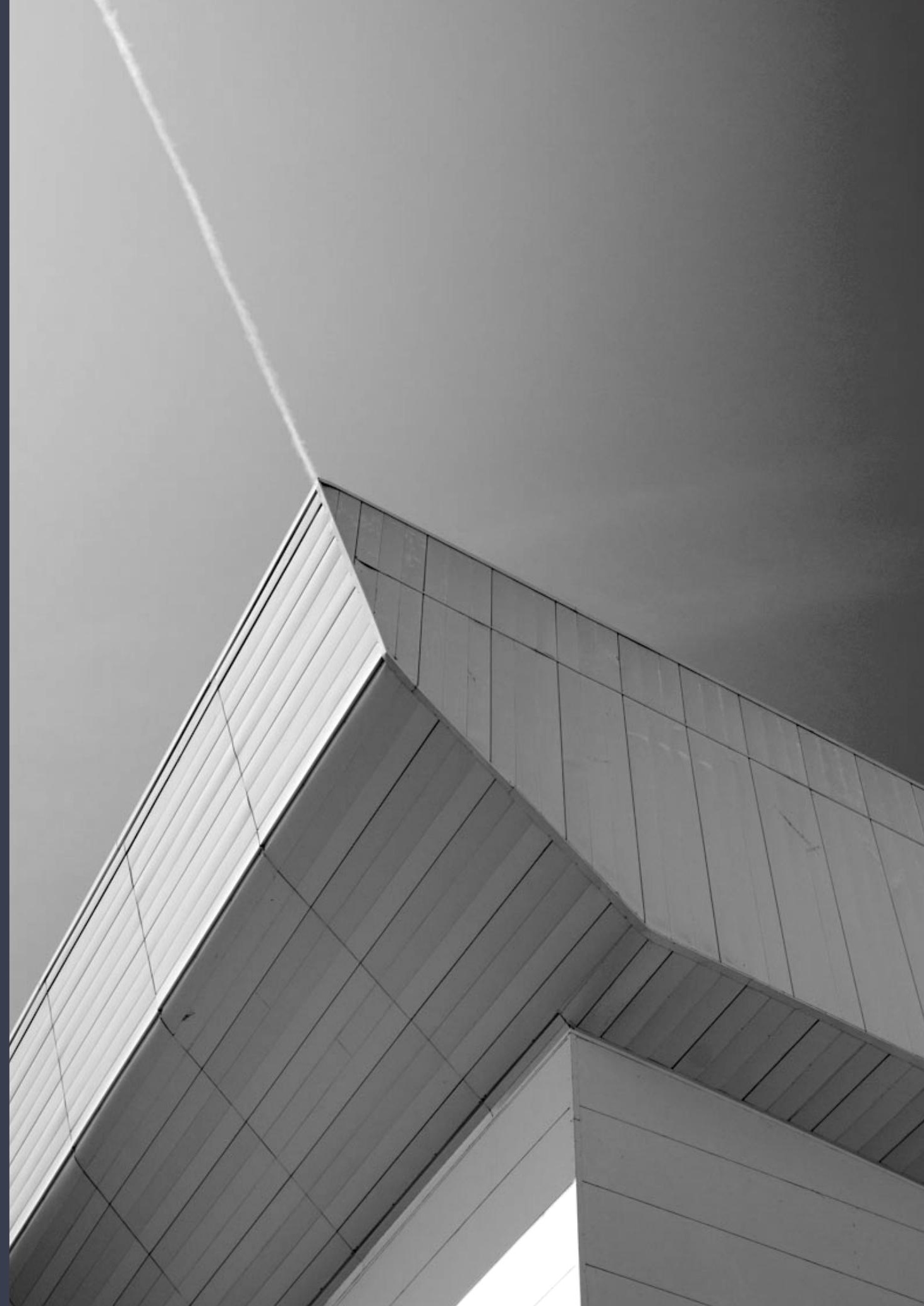




\section{Bazin olimpic acoperit Izvorani, piscina lotului olimpic de natație}

\section{Izvorani Olympic covered pool, swimming pool of the Olympic swimming team}

Bogdan TOFAN

bogdan.tofan@uauim.ro

Conf. Dr.Arhitect, SP*, FA UAUIM Assoc.Prof. Dr.Architect, SP*, FA UAUIM

*Departament Sinteza Proiectării de Arhitectură Facultatea de Arhitectură Universitatea de Arhitectură și Urbanism Ion Mincu * Synthesis of Architectural Design DAUIM București Faculty of Architecture Faculty of Architecture
Ion Mincu University of Architecture and Urbanism UAUIM Bucharest

\section{rezumat}

Așa cum am afirmat și în cadrul Bienalei de Arhitectură de la Veneția, în ediția din anul 2014, cred cu tărie că arhitectura este artă. Acest lucru ține de cultură. De asemeni astăzi în toata lumea civilizată arhitectura înseamnă tehnologie. în cazul ansamblurilor sportive tehnologia este o componentă necesară intrinsecă a construcțiilor destinate performanței sportive. Între constructiile destinate competițiilor sportive, piscina este una dintre cele mai complexe tehnologic. Toată măiestria constă în a îndeplini toate cerințele tehnice, și în plus, în a realiza un mesaj trimis peste timp celor cărora le place să înteleagă mai mult decât strict ceea ce văd în mod direct. cuvinte cheie

arhitectură, sport, studiu de caz, cercetare prin proiect abstract

As I said in the Venice Architecture Biennale, in the 2014 edition, I strongly believe that architecture is art. This is about culture. Also today in the civilized world architecture means technology. In the case of sports assemblies, technology is an intrinsically necessary component of the constructions intended for sports performance. Among the constructions for sports competitions, the pool is one of the most technologically complex. All the mastery consists in fulfilling all the technical requirements, and in addition, in realizing a message sent over time to those who like to understand more than strictly what they see directly.

keywords

architecture, sport, case study, research by design

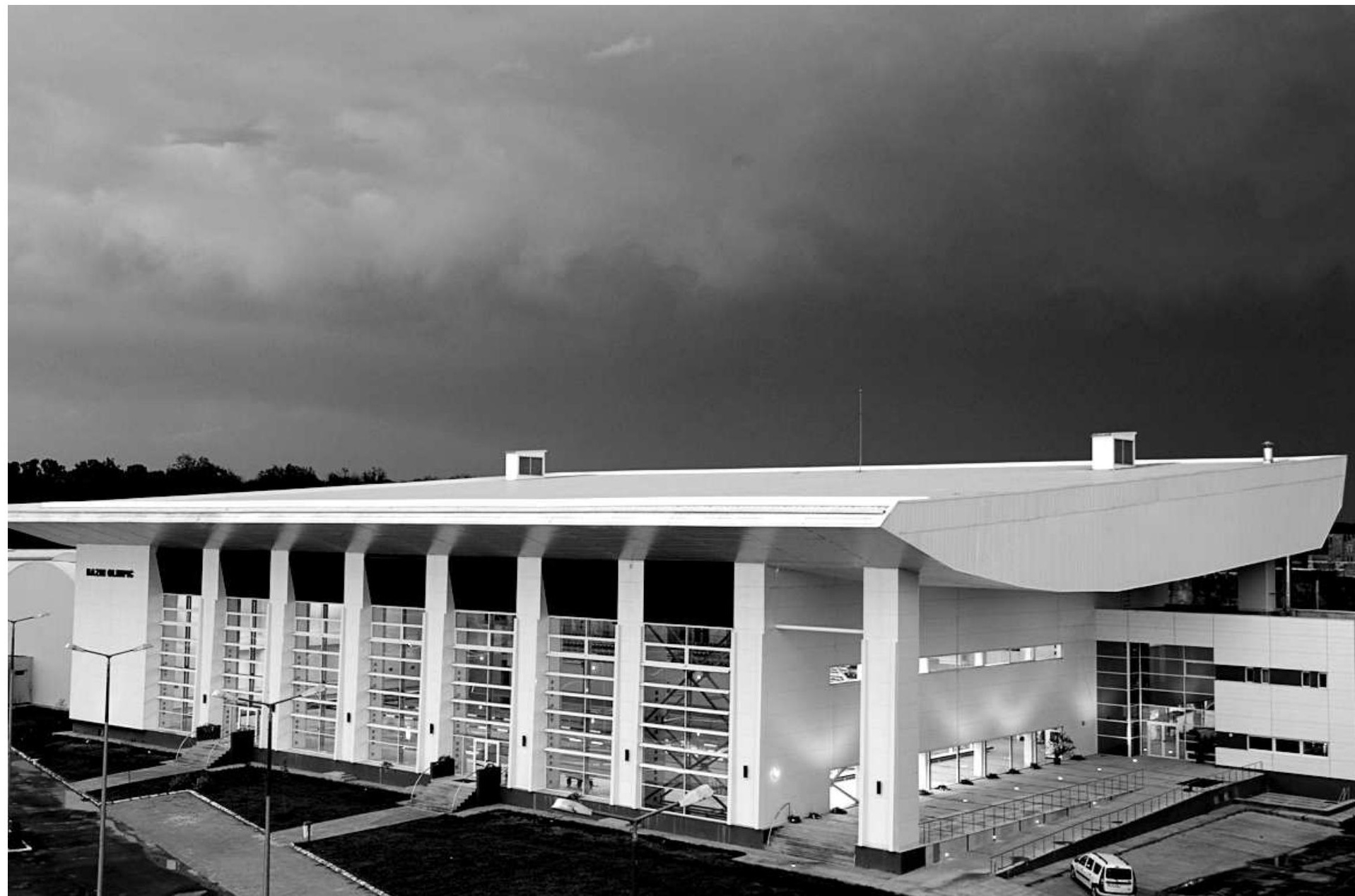




\section{Premise:}

Pământul are mare parte suprafața sa acoperită de apă = circa $70 \%$.

In mod similar corpul uman conține în structura sa circa $70 \%$ apă.

Ambele beneficiază de energie și dinamism.

Amplasamentul clădirii se află pe malul nordic al lacului Snagov.

Spectacolul acvatic al unui sportive surfer a fost cel care $\mathrm{m}$-a inspirat. Acesta conține toate elementele de bază: forță, curaj, intuiție, mișcare sinuoasă, lumină.

Inspirație:

Plutire pe un val virtual.

Mișcarea plăcii de surf a generat forma acoperișului construcției.

Din punct de vedere tehnic acoperișul general este înclinat într-o singură apă cu o pantă de cca $9 \%$. A fost studiată introducerea panourilor fotovoltaice în structura acoperișului. Imaginea exterioară de ansamblu a vrut să pună în valoare forma curbă a intradosului acoperișului. În zona de acces ia naștere un spațiu deschis acoperit care oferă publicului accesul principal în clădire. La sud s-a creat astfel un spațiu protejat. Intradosul acoperișului din această zonă sugerează o imagine cu urmă lăsată în apă după trecerea unui val.

Conform reglementărilor FINA (Federația Internațională de Natație), dimensiunile unui bazin olimpic cu 10 culoare de înot, sunt de $50 \times 25 \times 2$ metri. Înălțimea liberă minimă deasupra apei este de 
minim10 metri. În funcție de categoria concursurilor sportive această înălțime poate varia.

Natația înseamnă dinamism. În general, funcțiunea oricărei clădirii transpare în exterior. Dinamismul trebuia să fie dat de acoperiș, de un volum curb care să plutească în aer la o înălțime considerabilă și care să pară că poate glisa ușor pe un val imaginar. Aidoma unei planșe plutitoare de "surf" sau similar unei carene de șalupă brăzdând apa mării, volumul acoperișului trebuia să sugereze mișcarea, efortul înotătorilor, sportivilor cu idealuri olimpice. Încercând să dau o formă acestui edificiu, mi-am imaginat că am decupat un paralelipiped de apă cu aceste dimensiuni, prevăzute de FINA, în masa generală a lacului Snagov din apropiere. După decupare acest volum a fost "tras" pe mal și glisat în volumul construcției prin peretele sudic. A rămas astfel în urmă o fereastră de 25 m lățime pe 2 metri înălțime. A apărut astfel fanta orizontală de lumină ca urmare a transgresării volumului de apă prin peretele sudic al constructiei. Astfel volumul arhitectural păstrează pentru totdeauna amintirea operatiunilor mentale executate de arhitect.

La interior, printr-o coordonare complexă a proiectării pe specialități s-a realizat o imagine clară simplă, fără instalații vizibile. În clădire fluxurile majore de apă și de aer se mișcă în două planuri perpendicular unul pe celălalt: 1 . Circuitul apei în plan orizontal și 2. Circuitul aerului în plan tehnic vertical. S-au evitat pierderile de energie prin assezarea corectă a acestora în zonele de trasee comune. Tubulatura de ventilație a fost amplasată pe lângă masa de apă în așa fel încât să beneficieze de pierderi mici de energie. Duzele de suflare și introducere a aerului s-au amplasat în stâlpi în apropierea suprafețelor vitrate în așa fel încât să se evite fenomenul de aburire.

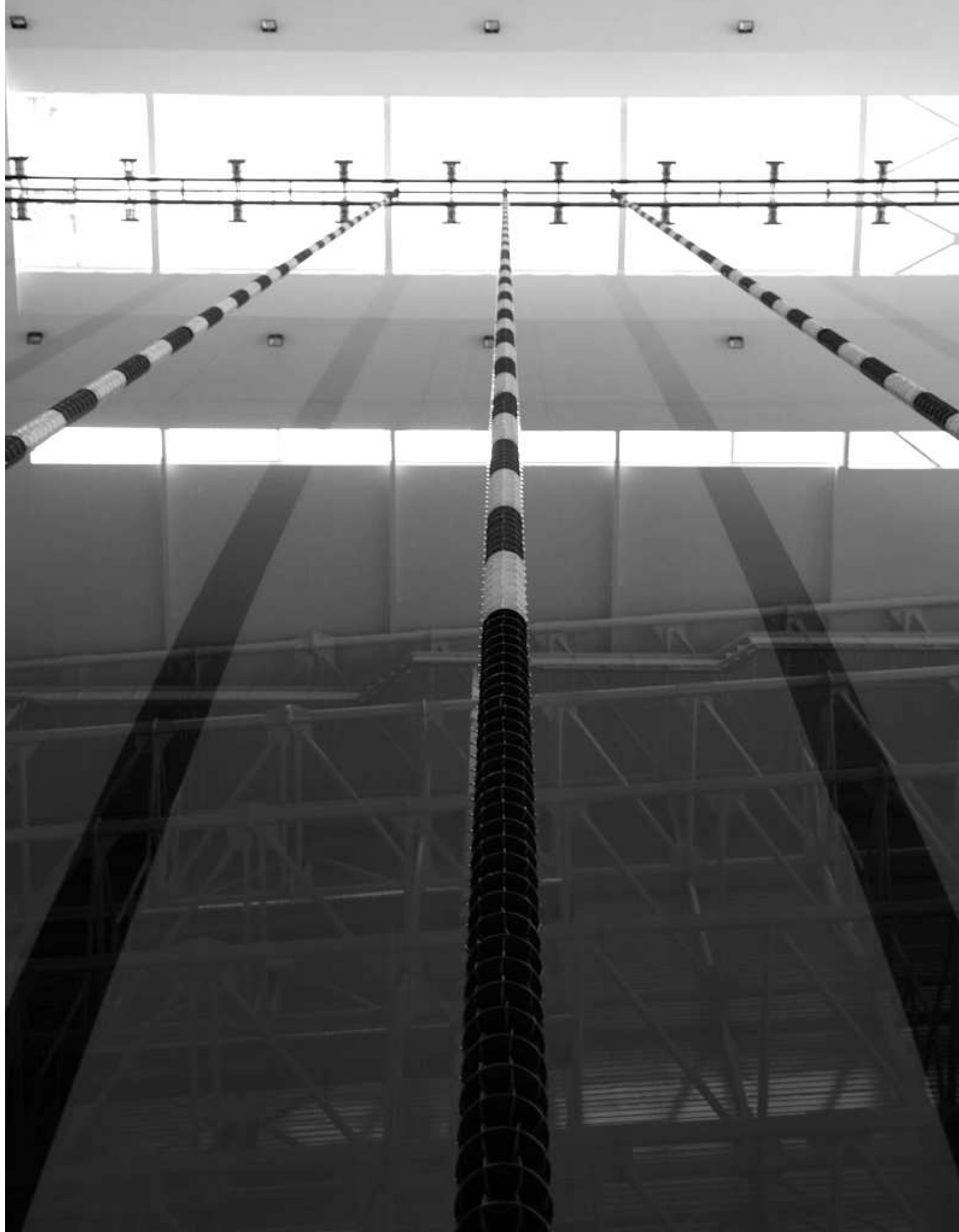


Pentru imaginea interioară, luciul oglinzii de apă este un element esențial compozițional. Ca spectator, stând așezat pe gradenă (de sub placa de surf) poți vedea reflectat în apă verdele gazonului de afară.

În fața studenților, (la prezentare), am expus un element particular de pe șantier, din sit. Studiul geotehnic executat pentru această lucrare a evidențiat un teren de fundare foarte dificil macroporic, sensibil la umezire. Acest tip de sol dă împingeri mari în structură și instalații, aspect foarte dificil mai ales în contextul unei piscine. În proiect sa prevăzut crearea unei perne de pământ calcinate în situ prin amestecarea solului cu nisip, ciment și var, lăsat să se stingă la fața locului. Acest fenomen de stingere în terenul de fundare a dat naștere unei planșete stabile calcinate cu o structură ce amintește de materialul din care sunt făcute stalactitele și stalagmitele într-o peșteră. Acest material nu mai este așa de sensibil la umezire păstrând volumul de apă într-o stare stabilă.

Am subliniat importanța naturii terenului de amplasament pentru orice clădire care urmează a fi realizată.

Un alt element de identitate al proiectului îl constituie tipul de stâlpi tubulari care permit trecerea tubulaturii de ventilație prin ei, la interior. Acesta a fost un aspect tehnic important. Interiorul piscinei este un spațiu umed cu o temperatură relativ ridicată de cca 26 de grade Celsius. Acest aspect de temperatură este specific piscinelor și are un impact asupra configurației fațadelor. Prin contrast cu forma curbă la intrados a acoperișului, corpul clădirii expune un ritm monoton de stâlpi. Aceștia sunt străbătuți de granița izo-termică a clădirii și susţin acoperișul. 
Circulația apei în clădire este rezolvată de echipamentele specifice, înglobate în structura edificiului. Aceasta presupune tratarea apei cu anumite substanțe special dozate în așa fel încât să nu depășească anumite limite atent monitorizate. Apa este pompată și introdusă în bazin prin intermediul a patru mari filtre de mare capacitate. Intre acestea și bazinul principal s-a realizat un rezervor tampon. Circuitul de filtrare are capacitatea de a schimba toată apa din bazin în 18 minute ceea ce la momentul construirii era o performanță mondială. Producătorul Myrtha Pools este o marcă recunoscută la nivel mondial în domeniul competițiilor de natație.

Toate aceste aspecte au constituit elemente specifice construirii Bazinului Olimpic de la Izvorani.

Fig.1-6* Clădirea Bazin Olimpic Izvorani / Izvorani Olympic Swimming Pool

*Imagini: Mestecăneanu Ș., imagini primite pentru publicare de la autorul articolului, Tofan B. / Image: Mestecăneanu Ș., images received for publication from the article's author Tofan $B$.

Fig.7-10** Proiect arhitectură: Clădirea Bazin Olimpic Izvorani /

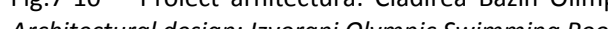
Architectural design: Izvorani Olympic
$* *$ Imagini: Tofan B. / images: Tofan B. 


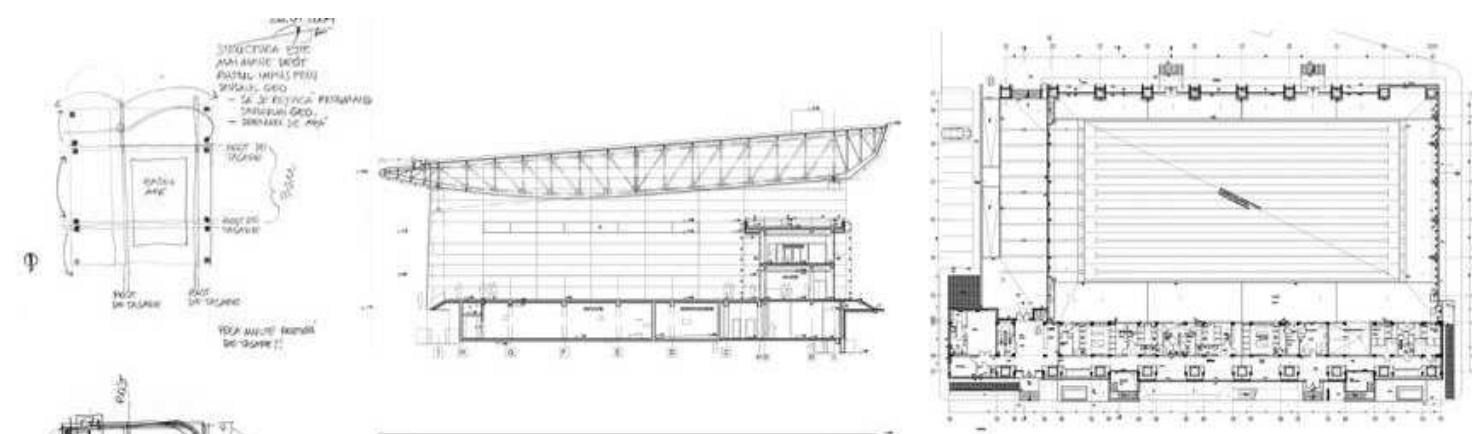

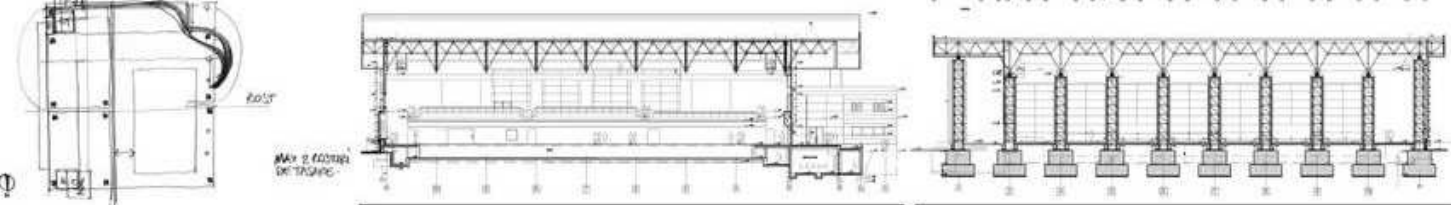
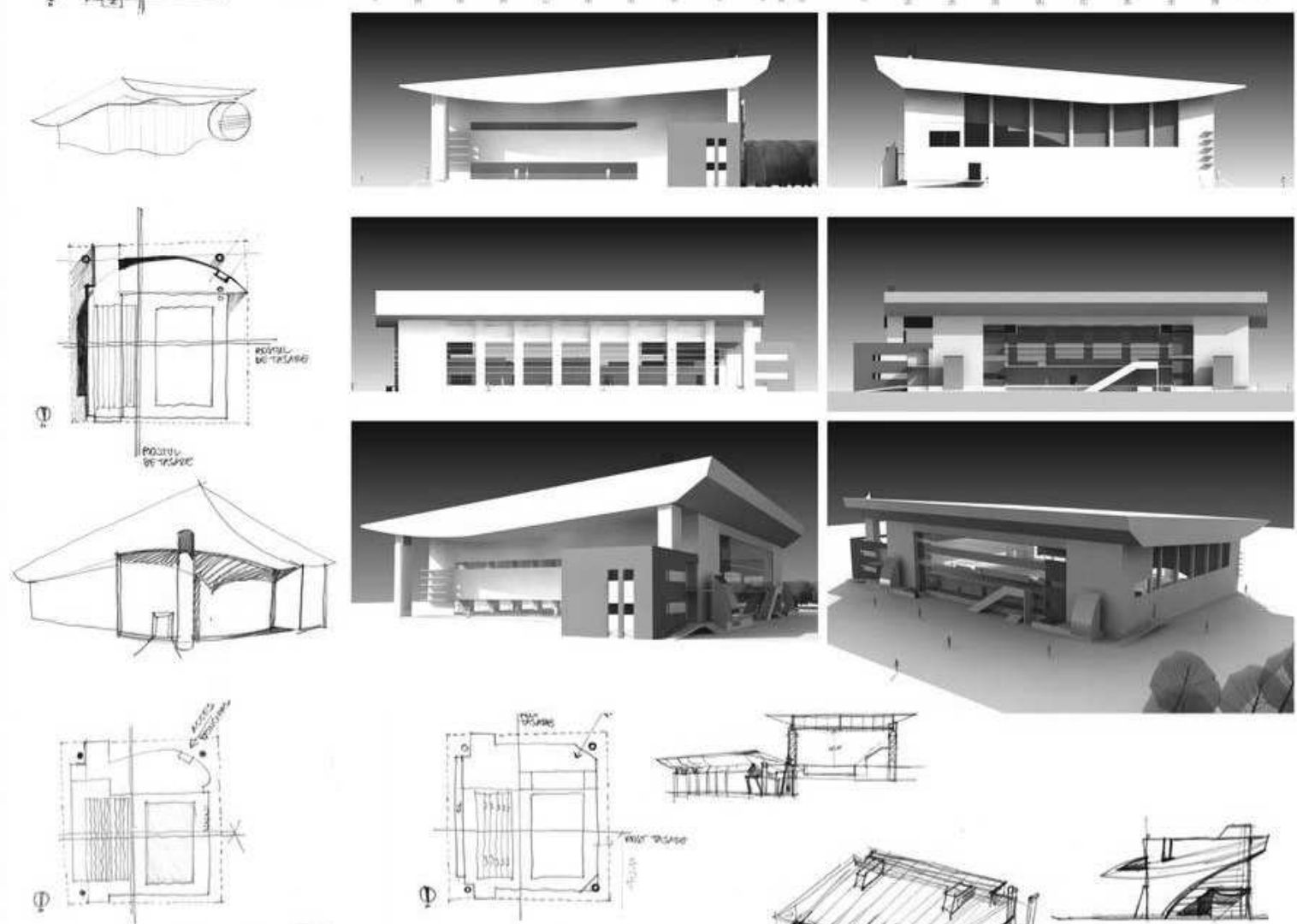

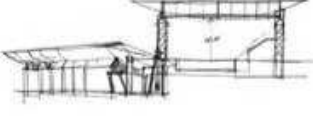
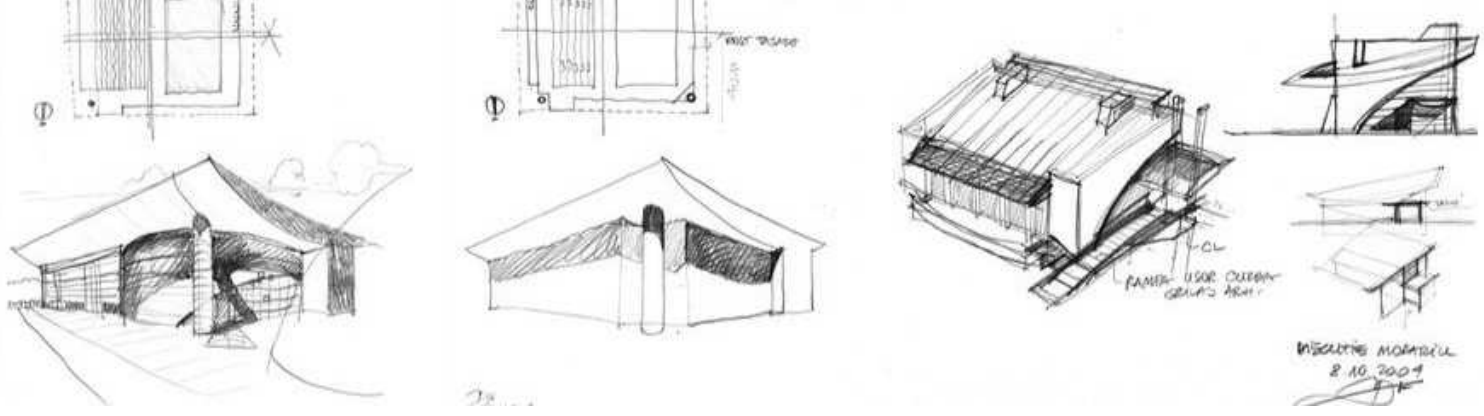

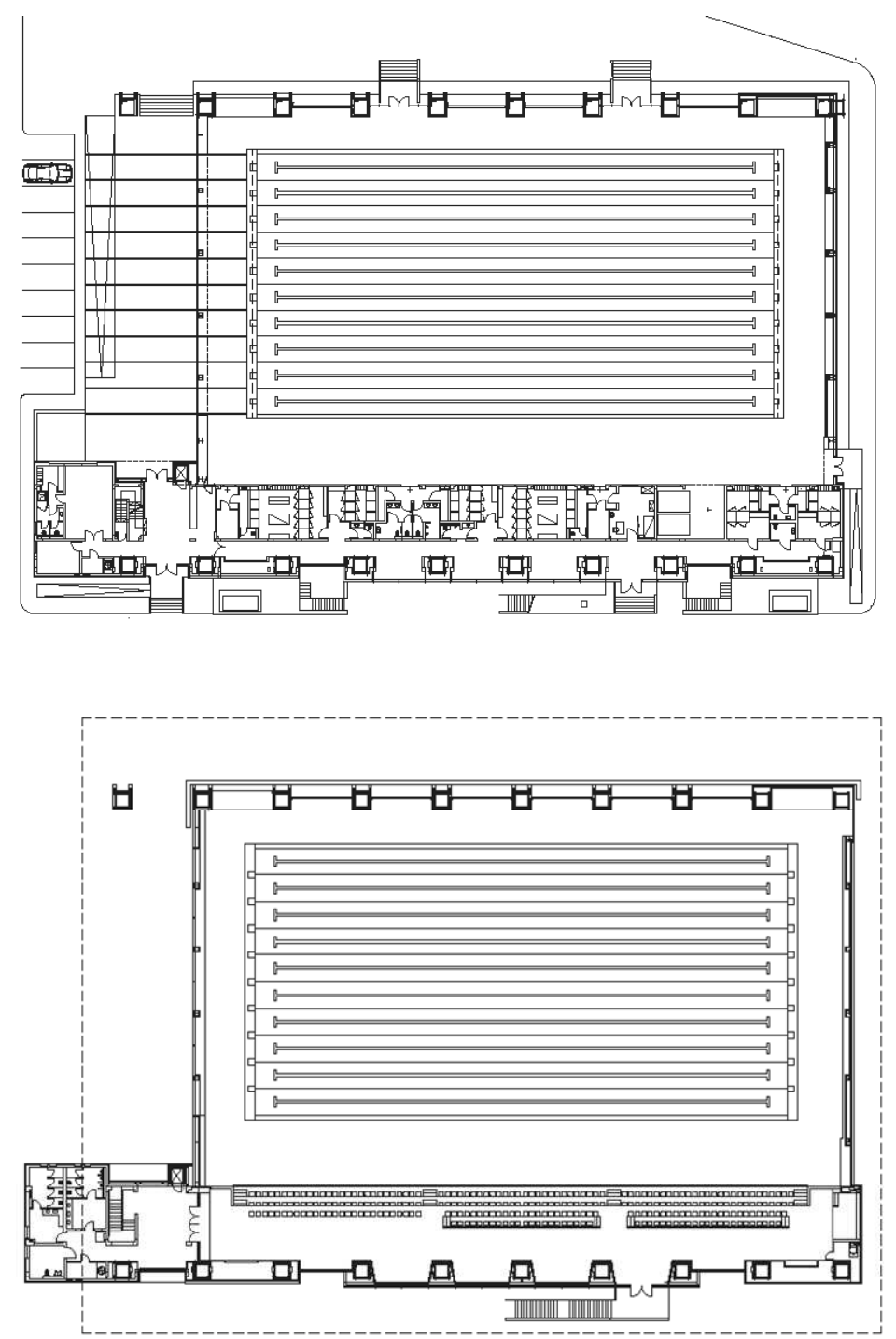

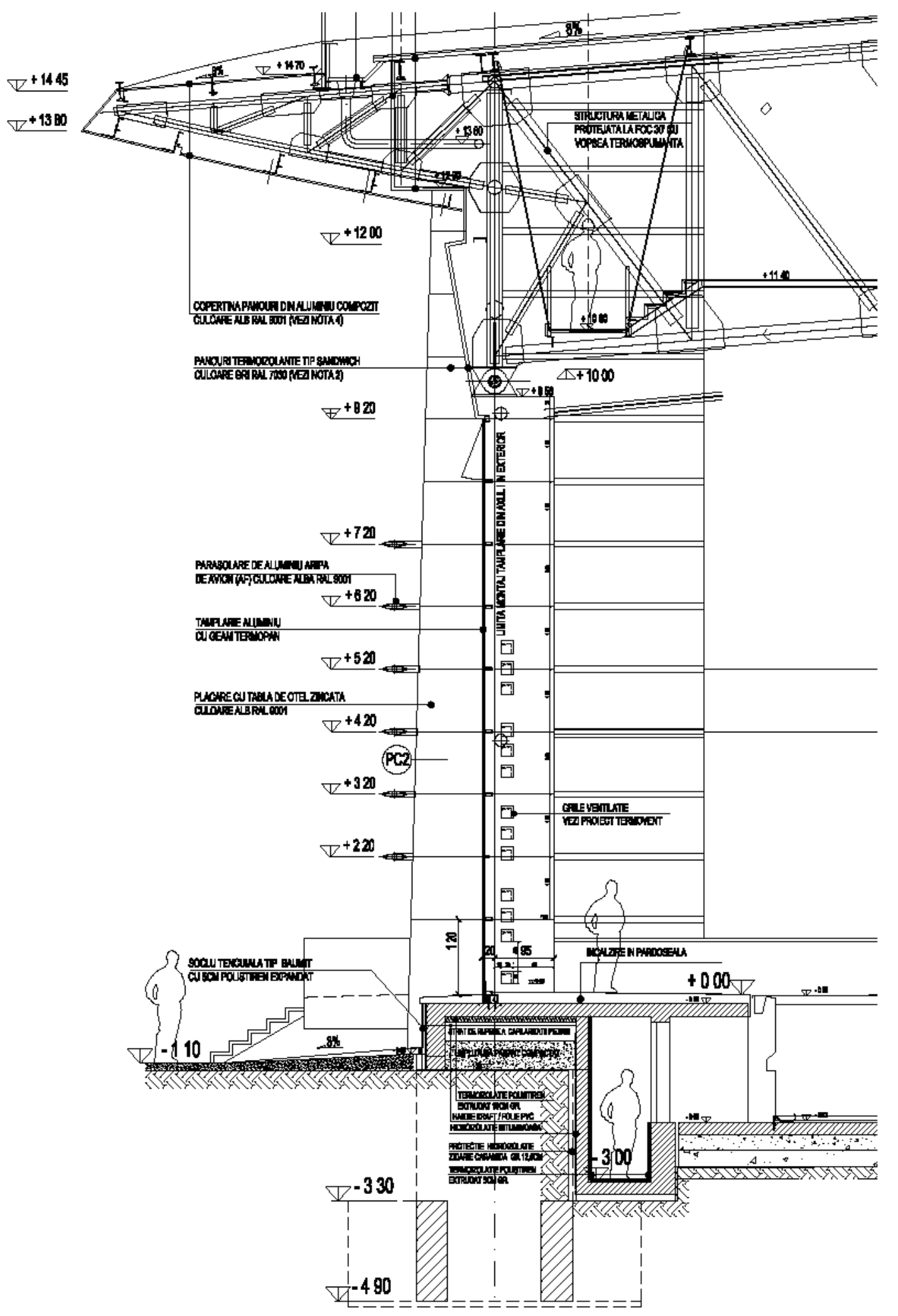


As I said in the Venice Architecture Biennale, in the 2014 edition, I strongly believe that architecture is art. This is about culture. Also today in the civilized world, architecture means technology. In the case of sports assemblies, technology is an intrinsically necessary component of the constructions intended for sports performance. Among the constructions for sports competitions, the pool is one of the most technologically complex. All the mastery consists in fulfilling all the technical requirements, and in addition, in realizing a message sent over time to those who like to understand more than strictly what they see directly.

In the open lesson that I have held at Ion Mincu University of Architecture and Urbanism (UAUIM), in the beautiful hall of the architects creators of heritage, I have stated (that) the architecture of a swimming pool, especially in the case of an Olympicgrade building, has a conceptual, but also practically, major connection with water energy.

Water is a living, active and intelligent matter. According to the concept that was the basis of the architectural creation in the case of the Olympic pool from Izvorani, Ilfov County, water is a material that can be worked with, modeled.

At the same time it is well known that in construction water is also a difficult, capricious material, constantly moving. A building must be well protected from water. Waterproofing and specific treatments are meticulously followed. The details have to be carefully designed both in the project and in the execution on the site. These are essential in this regard.
The earth has much of its surface covered by water = about $70 \%$.

Similarly, the human body contains about $70 \%$ water in its structure.

Both benefit from energy and dynamism.

The building's location is on the northern shore of Lake Snagov.

The water-show of a sport-surfer was the one that inspired me. It contains all the basic elements: strength, courage, intuition, and sinuous movement, light.

Inspiration:

Floating on a virtual wave.

The motion of the surfboard has generated the shape of the roof of the building.

From a technical point of view the general roof is inclined in a single direction with a slope of about 9\%. The introduction of photovoltaic panels into the roof structure was studied. The overall exterior image wanted to highlight the curved shape of the roof soffit. In the access area, there is a covered open space that gives the public the main access to the building. To the south, a protected space was created. The soffit of the roof in this area suggests footprint left in the water after passing a wave.

According to FINA (Federation Internationale de Natation / International Swimming Federation regulations, the dimensions of an Olympic swimming pool, with 10 swimming corridors, are $50 \times 25 \times 2$ meters. The minimum free height above the water is at least 10 meters. Depending on the category of sports competitions this height may vary. 
Swimming means dynamism. In general, the function of any building strikes towards exterior. The dynamism had to be given by the roof, of a curved volume that floats in the air at a considerable height and that seems to slide slightly on an imaginary wave. Aside from a floating surfboard or similar to a sailboat hovering over the sea water, the volume of the roof had to suggest movement, effort of swimmers, athletes with Olympic ideals. Trying to shape this building, I imagined that I cut a parallelepiped of water with these dimensions, presented by FINA, in the general mass of Lake Snagov nearby. After cutting this volume was "pulled" on the bank and slipped into the volume of construction through the south wall. It was thus left behind a window $25 \mathrm{~m}$ wide by 2 meters high. Thus, the horizontal light source appeared as a result of the transgression of the volume of water through the southern wall of the construction. Thus, the architectural volume keeps forever the memory of the mental operations performed by the architect.

Inside, through a complex coordination of the design on specialties, a clear simple image was obtained, without visible installations. In the building, the major flows of water and air move in two planes perpendicular to each other: 1. Water circuit in horizontal plane, and 2. Air circuit in vertical technical plane.

For the interior image, the gloss of the water mirror is an essential compositional element. As a spectator, sitting on the lawn (below the surfboard) you can see the green grass of the outside lawn reflected in the water.

Energy losses were avoided by correctly placing them in the common path areas. The ventilation pipe was placed near the water-mass so that as to benefit from small energy losses. The nozzles for blowing and introducing the air were placed in pillars near the glass surfaces so as to avoid the phenomenon of steam.

In front of the students, (at presentation), I exposed a particular element on the site, from the site. The geotechnical study carried out for this work highlighted a very difficult macro-pores foundation ground, sensitive to moisture. This type of soil gives great impetus to the structure and installations, a very difficult aspect especially in the context of a swimming pool. The project envisaged the creation of a ground cushion calcined in situ by mixing the soil with sand, cement and lime, left to extinguish on the spot. This phenomenon of extinction in the founding ground gave birth to a stable plateau calcined with a structure reminiscent of the material from which the stalactites and stalagmites are made in a cave. This material is no longer so sensitive to moisture, splitting the volume of water in a stable state.

I've underlined the importance of the site's nature for any building to be realized.

Another identity element of the project is the type of tubular pole that allows the passage of the ventilation pipe through them, inside. This was an important technical aspect. The interior of the pool is a moist space with a relatively high temperature of about 26 degrees Celsius. This aspect of temperature is specific to swimming pools and has an impact on the configuration of the facades. By contrast with the curved shape at the entrance of the roof the body of the building exposes a monotonous rhythm of poles. They are set by the iso-thermal boundary of the building and support the roof. 
The circulation of water in the building is solved by the specific equipments, and they have been included in the structure of the building. This involves treating the water with certain specially dosed substances so as not to exceed certain carefully monitored limits. The water is pumped and introduced into the basin through four large capacity filters. Between them and the main basin a buffer tank was made. The filtration circuit has the ability to change all the water in the basin in 18 minutes, which at the time of construction was a global performance. The manufacturer Myrtha Pools is a worldwide recognized brand in the field of swimming competitions.

All these aspects have constituted specific elements for the construction of the Izvorani Olympic Basin.

\section{Citare articol curent / Citation:}

(Ro)

Tofan B. (2021). Bazin olimpic acoperit Izvorani, piscina lotului olimpic de natație. în Teoria proiectului de arhitectură. Idei construite. SP FA UAUIM. EUIM - Editura Universitară Ion
consic de natatie. în Teoria proiectului de arhitectură. Idei Mincu, București.

(En)

Tofan B. (2021). Izvorani Olympic covered pool, swimming pool of the Olympic swimming team. in Architectural design theory. Built ideas. SP FA UAUIM. EUIM - Ion Mincu University Built ideas. SP FA UAUIM.
Publishing House, Bucharest. 


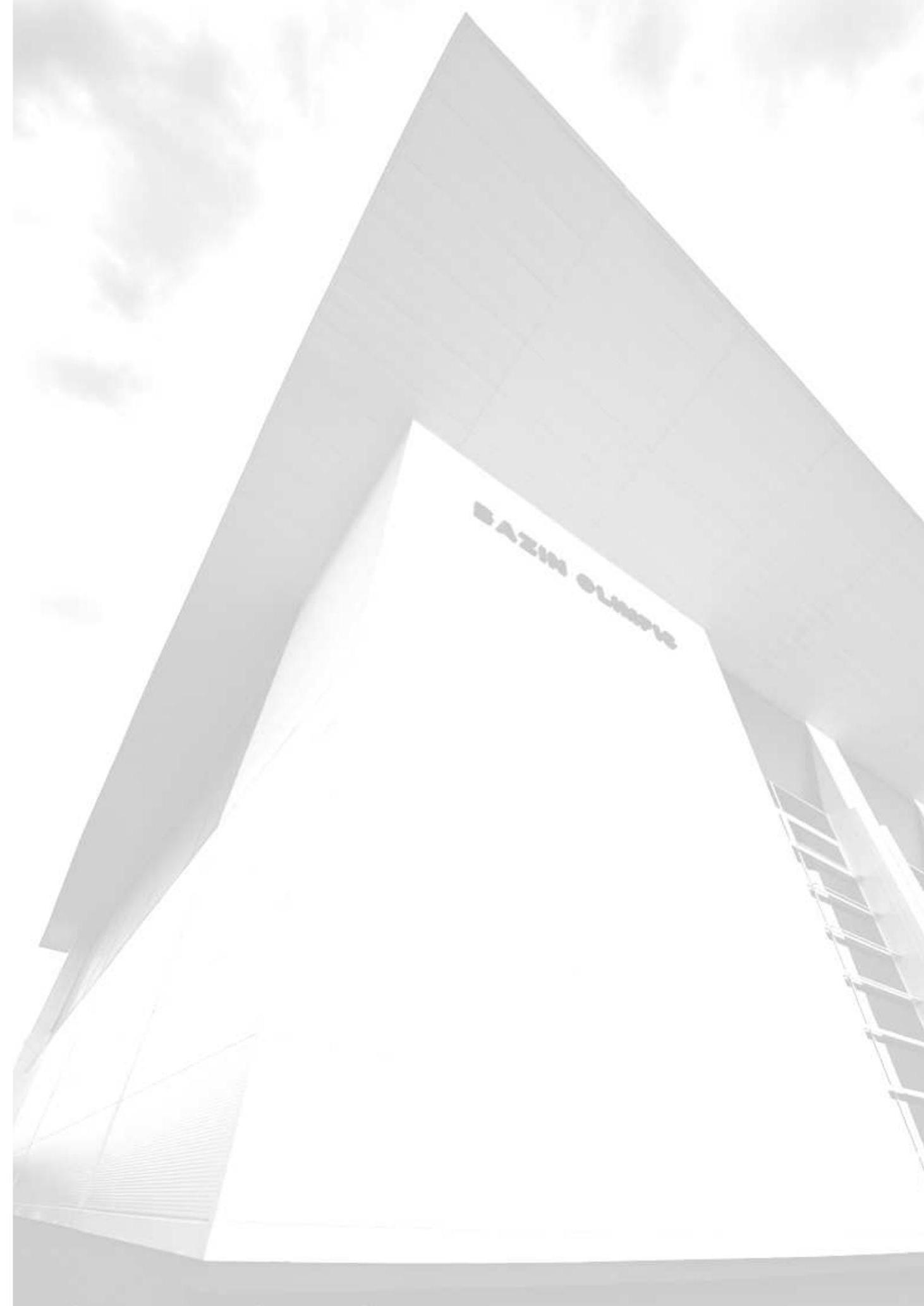

